\title{
Authentic learning for teaching reading: Foundation phase pre-service student teachers' learning experiences of creating and using digital stories in real classrooms
}

\begin{tabular}{|c|c|}
\hline \multicolumn{2}{|c|}{$\begin{array}{l}\text { Authors: } \\
\text { Trevor Moodley }{ }^{1} \\
\text { Shelley Aronstam² }\end{array}$} \\
\hline \multicolumn{2}{|c|}{$\begin{array}{l}\text { Affiliations: } \\
{ }^{1} \text { Department of Educational } \\
\text { Psychology, Faculty of } \\
\text { Education, University of the } \\
\text { Western Cape, South Africa }\end{array}$} \\
\hline \multicolumn{2}{|c|}{$\begin{array}{l}{ }^{2} \text { Faculty of Education, Cape } \\
\text { Peninsula University of } \\
\text { Technology, South Africa }\end{array}$} \\
\hline \multicolumn{2}{|c|}{$\begin{array}{l}\text { Corresponding author: } \\
\text { Trevor Moodley, } \\
\text { tmoodley@uwc.ac.za }\end{array}$} \\
\hline \multicolumn{2}{|c|}{$\begin{array}{l}\text { Dates: } \\
\text { Received: } 03 \text { Feb. } 2016 \\
\text { Accepted: } 19 \text { July } 2016 \\
\text { Published: } 24 \text { Oct. } 2016\end{array}$} \\
\hline \multicolumn{2}{|c|}{$\begin{array}{l}\text { How to cite this article: } \\
\text { Moodley, T. \& Aronstam, S., } \\
\text { 2016, 'Authentic learning for } \\
\text { teaching reading: Foundation } \\
\text { phase pre-service student } \\
\text { teachers' learning } \\
\text { experiences of creating and } \\
\text { using digital stories in real } \\
\text { classrooms', Reading \& } \\
\text { Writing } 7(1), \text { a129. http:// } \\
\text { dx.doi.org/10.4102/rw. } \\
\text { v7i1.129 }\end{array}$} \\
\hline \multicolumn{2}{|c|}{$\begin{array}{l}\text { Copyright: } \\
\text { (C) 2016. The Authors. } \\
\text { Licensee: AOSIS. This } \\
\text { is licensed under the } \\
\text { Creative Commons } \\
\text { Attribution License. }\end{array}$} \\
\hline \multicolumn{2}{|l|}{ Read online: } \\
\hline 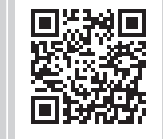 & $\begin{array}{l}\text { Scan this QR } \\
\text { code with your } \\
\text { smart phone or } \\
\text { mobile device } \\
\text { to read online. }\end{array}$ \\
\hline
\end{tabular}

Teaching and learning, an evolving endeavour, is associated with many factors, with advancements in technology, playing an ever-growing role in the classroom. It is therefore important to include the use of interactive communication technologies (ICTs) in university curricula of teacher education programmes. Universities ought to be creative in advancing autonomous learning among their students by providing opportunities for integrated and rich learning experiences. Accordingly, the purpose of this study was to intentionally integrate ICTs in the planning and delivery of foundation phase reading lessons. This was achieved by providing authentic learning opportunities to final year foundation phase student teachers through the provision of training in the creation of digital stories (DS), collaborating within communities of practice (COP) (peers and other relevant parties), and then using their creations in 'real-world' classroom contexts. The aims of this study were to explore student teachers' perceptions and experiences of developing DS in groups with minimal formal initial input and their use of DS during foundation phase (FP) reading lessons in real-class settings during teaching practice. Data were collected via focus group interviews and participants' reflection essays. The study's findings indicate that the creation of their own DS provided rich, rewarding multidimensional learning experiences to student teachers. Participants reported that they found the 'assignment' to be of real value, since it was directly linked to classroom practice, and despite the cognitive demands of the assignment; the nature of the task nurtured, an agentic disposition towards their own learning. Participants further reported that the DS provided enthusiasm among young learners during the delivery of lessons and were of pedagogical value, despite experiencing some challenges in using DS during reading lessons. Participants were of the view that the use of DS in advancing reading and literacy holds much pedagogical promise, because it resonates with the this generation of digital natives, the present generation of learners who have been born into a world where they interact with digital technology from an early age.

\section{Introduction}

The important role of storytelling in young children's learning experiences cannot be underestimated. Matthews-DeNatale (2008:2) supports this view by emphasising the close link between storytelling and meaning-making (the essence of learning in our view). Ohler further highlights the importance of storytelling in early learning experiences by stating:

The story form becomes a way to shape curricula, build units of instruction and frame academic arguments. Above all, stories become the cornerstone of constructivist learning in which students become heroes of their own learning adventures. (2008:9)

Ohler also stresses that the structure and rhythm of a story, as well as the emotional connection it elicits, assists with the recall of important information which might have been overlooked, if presented in the form of a lesson, lecture or report.

Our lives are increasingly being permeated by the use of technology, even in the ways we learn. Prensky (2001) emphasises this view by claiming that learners have changed because of the advent and rapid dissemination of digital technology in the last decades of the 20th century and its progression into the 21st century. In fact Prensky (2001:3) describes the current generation of learners as 'digital natives' - referring to people born during or after the introduction of digital technology, and those born before this period - as 'Digital Immigrants'. He further states that students graduating at present have spent less than $5000 \mathrm{~h}$ of their lives reading and over $10000 \mathrm{~h}$ 
playing video and/or computer games. Prensky also posits that the widespread use of technology and digital natives' high levels of interaction with it, has resulted in them thinking and processing information fundamentally differently from their predecessors (Prensky 2001:3). The majority of educators probably fall outside the category of digital natives. They therefore need to review and align their teaching methodologies for more relevant and effective learning experiences among their learners, the digital natives. Educators should therefore consider the role of technology in the classroom even when teaching literacy to young learners. Therefore, Beers, Beers and Smith (2010:8) caution that we can no longer only consider a single method of teaching reading and literacy to children.

Prensky highlights some of the challenges educators (digital immigrants) face today in teaching the current generation of learners. Firstly, many educators speak an outdated language (that of the pre-digital age) and therefore find it challenging to teach a generation of learners that speak an entirely new language (2001:2). Secondly digital natives appear to prefer the rapid receipt of information. This means that they prefer their graphics before text and games to 'serious' work: such digital natives demand instant gratification. Thirdly, many teachers who are digital immigrants assume that learners are the same as they have always been and that the same methods that worked in the past will work for learners today (Prensky 2001:3). These challenges seem to suggest a misfit between the type of learner today and the manner in which the curriculum is being delivered. This misfit may explain the constant complaint by many educators that learners find the classroom boring. Prensky too, highlights the misfit between digital natives and their digital immigrant teachers by posing the following question: 'Today's learners are different. Is it that Digital Natives can't pay attention, or that they choose not to?' (Prensky 2001:4).

Educators today need to reconsider both the content and methodology in their classrooms. Children born into any new culture learn a 'new language' easily. Therefore teachers have to learn to communicate in the language and style that best suits their learners. That does not necessarily mean changing the meaning of what is important or excluding the traditional curriculum. But as educators of the 21st century we need to adapt materials to the language of Digital Natives. The debate is no longer whether educators should use digital media, but rather how to use new media in a productive, creative way that will support learners in our classrooms.

Today learners inhabit a digital and oral world yet they reside in classrooms where the printed word is the predominant medium of instruction. Digital stories (DS) thus offer children the opportunity to interact with content in ways familiar to them. 'For many, digital is the language they speak and media is the environment in which they feel comfortable' (Ohler 2008:11). 'Technology plays an important role in the development of extended learning partnerships' (Beers et al. 2010:149). Technology challenges teachers to think outside the box. With technology in mind teachers need to be aware that children today live in a world that is different from the last century. Therefore in order for learners to have 'equitable opportunities to participate in a world that is changing rapidly, teachers need to ensure that children have the necessary fundamental skills' (Beers et al. 2010:150). When planning and structuring classroom programmes and curricula, teachers need to incorporate different media into learning environments to accommodate 21st century students.

The tradition of using printed books (hardcopies) as the primary means of teaching reading has been increasingly questioned as interactive communication technologies (ICTs) increasingly feature in teaching and learning. In fact, more than 10 years ago, Kress (2003) argued that the screen replaced the book as the central medium of communication. Techniques of sound, image and colour continue to have enduring effects on the form and function of reading as digital modes which offer different and unique ways of communicating the meaning of a message. Teachers have a responsibility to incorporate digital technologies into their literacy programmes to prepare learners by means of new modes of reading and writing that are prevalent in their world; not just limiting them to using traditional paper readers and big books (Javorsky \& Trainin 2014:607).

There are different definitions of digital storytelling. Robin (2008:222) considers DS to include the conventional means of creating a story through topic selection, doing research and then writing a script. The story is then transformed and enhanced in digital format using a computer and employing various digital multimedia such as images, audio and video. Matthews-DeNatale (2008:2) quotes the Digital Story Association's definition of digital storytelling as 'the modern expression of the ancient art of storytelling. ... Stories have taken many different forms. Stories have been adapted to each successive medium that has emerged, from the circle of the campfire to the silver screen, and now the computer screen'.

DS can be an effective way of teaching literacy to young learners who, according to Kikokawa (2010), live mediasaturated lives: they are consistently exposed to different media such as mobile phones, laptops, the internet, video games and other electronic visual media. DS should be understood within the context of the curriculum in the classroom. Reading text is no longer only linear and static. It does not only refer to words on a page. Nowadays, images play a more important role in conveying information in an educational setting. Written texts can be highly visual but the teacher needs to take into consideration the links between visual and written words by exploring and experimenting with texts. When teachers take into consideration that dialogue and discussion are a vital part of the learning strategy then visual literacy should be used as a guideline in learning how to formulate questions relating to and incorporating the visual text (Ohler 2008:14). 
The screen and the book are two different forms of media; they have a lot in common in terms of reading. They both require the reader to interpret text through decoding, analysing, predicting and identifying words. DS in a multimedia environment offers the opportunity for pictures to be animated and this feature can be used as a cueing system to assist readers who are struggling to read. However, animation and constant movement can hinder young children and distract their attention away from the words in the text. Visual media is an ideal way of attracting reluctant readers and has the potential to teach the basic skills of reading and writing as well as enabling young children to focus their attention on specific aspects of teaching reading (Kress 2003).

Digital Literacy has added a further dimension to a complex discussion about phonics versus whole language in the teaching of reading. Dialogue about books versus multimedia is taking place in educational forums around the world and studies are being conducted on the strengths and weaknesses of its use in classrooms. Educators need to recognise the emergent proficiency that children can bring to a multimedia learning environment as they expose children to new words in rich and meaningful contexts (Kress 2003).

Teachers need to decide how best DS can support and enrich the reading programmes in their classrooms. They should address the aims of teaching children to read by providing a secure foundation in developing the skills of reading with accuracy, fluency, comprehension and enjoyment.

\section{Theoretical framework}

The theoretical framework for this study links the theory of reflective practice (Schön 1983, 1987) with authentic learning theory (Reeves, Herrington \& Oliver 2002; Rule 2006). Reflective practice has become a common term used to describe a variety of activities in teacher education programmes (Loughran 2002). Schön $(1983,1987)$ defines reflective practice at its best as an experience which involves thoughtfully considering one's own experiences in applying knowledge to practise while being coached by professionals in the discipline. Reflective practice is an evolving concept that has been influenced by various philosophical and pedagogical theories (Florez 2001). Reflection can be described in three phases, or modes: (1) reflection in practice, or the dynamic, 'thinking on your feet' a teacher does during a lesson; (2) reflection on practice, the reflection that occurs post instruction, when a teacher thinks in hindsight about the lesson, student engagements, and other components of the experience; and (3) reflection for practice, the thinking about future experience informed by the past practice ... what now needs to occur coming from the reflection of the past (Schön 1983).

The project described in this article, was designed to offer student teachers the opportunity to become actively involved in their learning when creating their DS. The intention was to promote learning and skills development in different domains, without the comfort of providing student teachers (as learners) with a detailed script of how and what to do. Thus, the project was designed with the intention of engaging student teachers in authentic learning. Ryan et al. (2009) claim that authentic learning experiences significantly enhance professional learning. Authentic learning resonates with the notions of situated learning and communities of practice (COP). Situated learning focusses on the relationship between learning and the social relationships in which it occurs (Lave \& Wenger 1991:14). Situated learning focusses on the learner acquiring skills through participation in the process rather than gaining abstract knowledge (Lave \& Wenger 1991:14). At its core, situated learning is characterised by the process of legitimate peripheral participation which emphasises that learners acquire knowledge and the mastery of skills through participation in COP (p. 29). COP imply that participants share understandings concerning what they are doing and what that means in their lives and for their communities (p. 98).

After reviewing a number of journal articles dealing with the subject of authentic learning, Rule (2006) identifies four overarching themes that support authentic learning. These themes are 1) the activity involves real-world problems that mimic the work of professionals in the discipline with presentation of findings to audiences beyond the classroom; 2) open-ended inquiry, thinking skills, and metacognition are addressed; 3) students engage in discourse and social learning in a community of learners; and 4) students are empowered through choice to direct their own learning in relevant project work (Rule 2006:2).

In another review of literature related to authentic learning, Reeves et al. (2002:563) identify ten design characteristics of authentic activities: (1) relevant to the real world; (2) not clearly defined giving learners the responsibility to clarify task goals and specific actions needed to complete the task; (3) involve complex tasks that learners have to perform a considerable period of time; (4) encourage multiple perspectives and the use of a variety of resources; (5) encourage collaboration, (6) provide opportunities for reflection; (7) they can be applied across different subject areas, thus promoting interdisciplinary perspectives, (8) they can be easily linked to assessment; (9) they provide valuable outputs that can be of use in the real world; (10) the nature of the tasks allow for multiple solutions rather than arriving at a single correct solution after having followed a script.

\section{Methodology Description of the study}

As a literacy lecturer, the researcher concurs with Leu, Kinzer, Coiro and Cammack as noted in Larson (2010:15) that in 'today's classrooms, reading instruction, along with the broader notion of literacy instruction, is undergoing tremendous transformations as new technologies demand new literacy skills'. Thus, this pilot project was carried out in 2013 with final year pre-service foundation phase (FP) students in the Education Faculty at a university of technology located in the Western Cape. 
There are different definitions of the term, 'literacy'. One such definition is proposed in The Education for All Global Monitoring Report (UNESCO 2005) that defines literacy as a set of demonstrated skills, particularly the cognitive skills of reading and writing. The International Literacy Association (ILA) highlights the need for educators to integrate ICTs into their existing literacy programmes (Larson 2010:15). One of the ways of doing this is to clarify and outline what constitutes text. Bearne (2005:16) highlights the evolution in the meaning of 'text' by stating that young readers have access to a large range of texts 'in different combinations of modes and media so that "text" has come to include not only words-plus-images but moving images, with associated sound-tracks too'.

With the aim of intentionally integrating ICTs in the delivery of foundation phase (FP) reading lessons, final year FP student teachers were given four sessions of input on traditional storytelling and digital storytelling. Instructors from the university's teaching and learning higher education development unit delivered and demonstrated to students how to plan and design a storyboard and produce a digital story. The following categories were addressed: elements of a story, story mapping templates, pre-production, production and post -production. Software 'Movie Maker', PowerPoint, artwork, images and copyright constraints were discussed. Support was provided with voice recordings, sound, music and assembling the final product.

Students worked in groups of four. These groups were self-selected, based on language: the students had to write a script that they could use with their learners when they went into their chosen schools during teaching practice. Production of the stories took place both on and off campus during the student's free time. Before their final completion, student groups had the opportunity to present their stories to the rest of their peers and to two of their lecturers and some of the staff from the university's higher education support unit. Students were given feedback on changes that could be implemented before they used them in their teaching practice classrooms.

\section{Aims of the study}

The aims of this study was to explore student teachers' perceptions and experiences of developing DS in groups with minimal formal initial input and their use of DS during FP reading lessons in real-class settings during teaching practice.

After teaching practice, students were required to write a reflective essay about their experiences in designing their own DS in groups and their experiences of using DS in actual FP reading lessons.

Given the research aims of the study, it was deemed appropriate to conduct the study within an interpretivist paradigm of enquiry which does not subscribe to a single objective, observable reality: reality is socially constructed with multiple interpretations and realities related to a single event (Merriam 2009). Methodology within the interpretive paradigm can be described as 'interactional, interpretive and qualitative' in nature (Terre Blanche \& Durrheim 1999:6). In line with the interpretivist paradigm, a qualitative research approach was followed. Qualitative researchers have an interest in how people make sense of their world and experiences of the world (Merriam 2009:13). 'Qualitative research provides information about the "human" side of an issue - that is, the often contradictory behaviors, beliefs, opinions, emotions, and relationships of individuals' (Mack et al. 2005:1).

Prior to the commencement of this study, ethical measures were taken, and included: gaining permission to conduct the study form the Faculty Ethics Committee of the university concerned, emphasising the principles of informed consent, voluntary participation and withdrawal, anonymity and confidentiality for all participants. It was emphasised that the study was independent of students' academic progress and that those who chose not to participate would not be disadvantaged in any way. Thus all final year students received training and a task in developing a digital story.

\section{Data collection}

Two modes of data collection were employed in this study as a means of triangulating the data to improve the validity of the study. Firstly, participants were required to write a reflective essay about their perceptions and experiences of designing DS in groups and use these DS in real-classroom lessons during teaching practice. The researchers intentionally did not give participants too many prescriptions in writing their reflections because we were hoping that an unstructured approach to writing would reveal what perceptions and experiences individuals considered significant enough to warrant mention in their essays. Participants were already familiar with the writing of reflections, because reflections are an integral aspect of the university's FP undergraduate degree curriculum, with a particular focus on specific theoretical input about reflection in their previous year of study. This input included learning about the value of reflective practice in teacher education (Korthagen 2001; Shulman \& Shulman 2004), the challenges of learning to become reflective practitioners and different writings related to reflective practice. Secondly, two focus group interviews, with eight participants per group, were conducted to explore participants' perceptions and experiences about designing DS in groups and also using the DS when delivering reading lessons in FP classrooms during teaching practice.

\section{Data analysis}

Data were analysed using a process of thematic analysis involving six recursive steps (Braun \& Clarke 2006; Clarke \& Braun 2013). The steps included the researchers: familiarising themselves with the data, coding the data, identifying themes from the coded data, reviewing themes to gauge the extent to 
which they represent the data set and whether themes could be refined, by defining and naming the themes and lastly writing up the themes in a coherent and meaningful manner that is manifest in the Results and discussion section. Firstly, the written reflections were analysed and themes were identified. Next, the focus group interviews were transcribed and analysed to identify themes. Validity of the study was secured by each of the researchers firstly individually analysing and coding the data sources. Next each researcher constantly compared the analyses of the two sources of data. Lastly the researchers teamed up to compare their individual analyses and deliberate on the final analysis of the data.

\section{Findings and discussion}

In response to the first aim of the study, the study's findings indicated that student teachers' experiences of developing DS within groups provided them with multiple opportunities to enhance technological and pedagogical content knowledge within COP. A number of themes were identified and included those that resonated with Reeves et al. (2002) ten characteristics of authentic learning, Rule's four themes related to authentic learning as well as Schön's model of reflection (1983). The themes are:

\section{Real and meaningful learning through the creation of digital stories}

Participants mentioned that the DS assignment had real value beyond the stereotypical role of assignments for the purposes of assessment. The creation of their own DS provided student teachers with an authentic learning opportunity to develop valuable skills and knowledge relevant to the real world (Reeves et al. 2002:563) of professional teacher-training. Student teachers used the DS during actual reading lessons in real schools, with learners in the presence of their mentor teachers. The nature of these endeavours resonated with Reeves et al. (2002:563) who consider that authentic learning ought to produce valuable outputs for use in the real world. The learning activity corresponded with Rule's (2006:2) contention that authentic learning involves presenting the products of learning (DS in this instance) to an audience (FP learners and mentor teachers) while 'mimic[ing] the work of professionals in the discipline' (Rule 2006:2) (teaching actual reading lessons during actual lessons). The meaningful learning gained by students in creating their own DS is aptly summed up by Chung's (2006:45) claim that students produce their own knowledge when creating DS and invest 'emotional substance' in their narrations which highlight the authentic learning character of such an activity. The following excerpts substantiate this view and reflect the authentic learning characteristics and/or themes discussed in this section:

As a student teacher I am really thankful that I have been introduced to DS and how to create them. This is a useful tool that I will be able to use in my own class next year. If ' $D$ ' [D.S. workshop facilitator] hadn't given us the training I would not have known about the different software programmes. I had written an ordinary story but never thought about doing it digitally until we got this assignment. [Female final year foundation phase student teacher]

I am actually glad that we drew the pictures for the story and didn't take pictures from the computer. The children mentioned it - they were 'wow look at the pictures did you draw them miss?' In a way it makes it more authentic. I am so proud of what I did because I don't see myself as a drawer. [Female final year foundation phase student teacher]

When I think of children today and where they are at - watching TV, playing video games, computers etc. If you don't go along with all that you are going to lose them because that is what excites them, it is their world. You need to think about what they want and not what the teacher wants. It's their needs, their interests that's important. [Female final year foundation phase student teacher]

\section{Student teacher agency and improvisation in creating digital stories}

After receiving some training in designing DS, participants were asked to design their own DS that would be appropriate for use during reading lessons in the FP. Thus, they were not expected to adhere to a preconceived list of strict criteria. The findings revealed that participants took initiative in finding information and support from different sources with respect to different aspects of the digital story creation. Individuals within groups identified their own strengths and identified support networks outside the group such as family members with relevant ICT skills, and selfteaching by using free instructional digital story creation software on the internet. They improvised by using mobile phones as substitutes for headphones. Consequently, and characteristically of authentic learning activities, students were left with the responsibility of clarifying task goals and specific actions (Reeves et al. 2002:563), empowering themselves by directing their own learning (Rule 2006:2), and learning from multiple perspectives and using different resources (Reeves et al. 2002:563).

The following excerpts illustrate the agentic efforts of groups in clarifying their own task goals and taking specific actions:

I did the technological aspects because I had worked on photo story before. We all worked on the text together and decided who was going to be the narrators. ' $\mathrm{N}$ ' scanned and uploaded the pictures as I wasn't able to do that. [Female final year foundation phase student teacher]

The training was good. It was a nice foundation for us to explore on our own. You can't be afraid of the technology, you just need to play around with it. [Female final year foundation phase student teacher]

I recall 'D' [D.S. workshop facilitator] explaining what photo story would allow me to do. She showed us a videoclip on how to put it together but I took myself through the process and played around once I had downloaded the programme. I experimented. [Female final year foundation phase student teacher]

There is so much that you can really do with the programme, you have to really sit and explore. You need to know the 
different programmes. [Female final year foundation phase student teacher]

I'm really glad we drew our own pictures as opposed to using somebody else's. You think more about it and ways to use it. [Female final year foundation phase student teacher]

\section{The creation of digital stories: A complex and daunting task}

Developing DS was daunting as it compelled student teachers to consider pedagogical content knowledge when designing stories and at the same time developing and accessing a host of ICT skills and knowledge in order to produce stories in digital format. Participants reported that they felt intimidated initially about creating DS, but that the eventual outcome was awesome and motivated them to produce more stories in digital format, even though the process involved a substantial amount of time. They mentioned that DS creation provided learning and entertainment, which was quite unlike their experiences in doing assignments in the traditional paper and pencil format. The assignment task reflected the authentic learning characteristics of being open-ended (Rule 2006:2), complex and time-consuming (Reeves et al. 2002:563). Xu, Park and Baek (2011:189) highlight the complex nature of creating DS by claiming that DS are a form of communication: as they are created, students apply critical thinking skills while selecting the appropriate media to convey the story's message to the audience. They provide the student with a learning environment to apply communication skills, work collaboratively, and think critically while addressing content and technology standards. The pedagogies thus employed in facilitating student teachers' learning in the creation and use of DS reflect O'Hara's (2007) view that pedagogies need to change if learners are to be adequately prepared to thrive in the emerging global knowledge society, O'Hara (2007:937) highlighted the need for pedagogy 'to shift from its current primary focus on the mastery of content to one on process from a focus on "knowledge" the noun, to a focus on "learning" the verb'. O'Hara (2007:937) underlined the need for pedagogy to focus more on open-ended emergent outcomes than predetermined outcomes.

The following excerpts reflect the open-ended, complex and time-consuming nature of the assignment task:

It shows the children that we as student teachers can draw. It takes time. [Female final year foundation phase student teacher]

We changed the narrator quite a few times because I heard myself and my first few attempts I read very quickly. I realised I was reading for myself. It took me a while to read slower. I read to my younger cousins which helped a lot. Every time I read I would keep them in mind and then once I was done I had them listen to the story. [Female final year foundation phase student teacher]

Next time you should tell the students [student teachers] to create a story before they come to the training. We were worried that we didn't have enough time for our scripts. You want to sit and put effort in. [Female final year foundation phase student teacher]
We all had different jobs especially with the narration, recording, putting together, software etc. We tried to use what was our strengths. [Female final year foundation phase student teacher]

\section{Learning within communities of practice in a higher education setting}

As participants created DS in groups, they reported that they had to listen to individual views when making decisions. Participants accessed in-group resources (pedagogical and technical skills) and identified resources outside groups, especially in relation to technological skills and knowledge required in creating DS. The collaboration that occurred in developing DS are consistent with Wenger's (1998) claim that COP are characterised by three elements, namely: mutual engagement, joint enterprises and a shared repertoire. Members of a COP engage with each other through mutual engagement in an activity (joint enterprise). Members negotiate meaning with one another as they go about pursuing the goals of the activity (Wenger 1998:73-82). The task encouraged and demanded multiple perspectives and much collaboration thus subscribing to the notion of a COP. Through this COP approach to learning, a variety of stories were created by different groups of students for different FP grades. The students then shared the stories with each other, thus enhancing students' learning experiences and demonstrating the value of the learning task. The individual as well as the collaborative efforts and initiatives taken by the student teachers in creating DS reflected a shared epistemic agency which is:

the capacity to enable a deliberate, joint, object-oriented interaction ... express[ing] different qualities of the knowledge co-construction process. The epistemic aspect refers to the active involvement of the group with knowledge and its materialization into knowledge objects. ... Sharedness implies that agency is not the expression of each individual member's activities or pursuits but is, rather, the expression of joint efforts at the group level ..., shared epistemic agency is seen as an emerging, recursive capacity that manifests itself and unfolds during the interaction. (Damşa 2014:255)

The following excerpts reflect the authentic task characteristics of collaboration (Reeves et al. 2006:563) within a COP (Rule 2006:2) and encouraging multiple perspectives:

We all came together and discussed the assignment and then we wrote down ideas and collaborated with the actual story. We all wrote it together. None of us can draw so ' $\mathrm{N}$ ' drew the outline of the pictures and we coloured them in. We all dived on google for images for her to copy, use or trace. [Female final year foundation phase student teacher]

We were sitting together as a group and I said I have a story and ' $C$ ' said she had also written a story. So we looked at the two and settled on mine. It was in Afrikaans so we translated it, condensed it and put it into a format that kind of flowed together. The essence of the story remained the same. [Female final year foundation phase student teacher]

I don't think teachers know that you can actually make a story like this. At the schools there are young teachers out there who are advanced with ipads etc. but are still not teaching using 
digital media. They are busy and don't share and work together. [Female final year foundation phase student teacher]

\section{Reflection: A key characteristic of authentic learning and professional teacher education}

Students' reflections included elements of Schön's (1983) conceptualisation of reflection as involving three modes or phases, namely: (1) reflection in practice (teacher reflecting while teaching- 'thinking on your feet'), (2) reflection on practice (the reflection that takes place post instruction) and (3) reflection for practice, (reflecting about possibilities related to future lessons based on past teaching experiences).

\section{The following excerpts demonstrate reflection in practice:}

The sound wasn't clear and the children were getting restless so I turned the sound off and decided to read the story instead. [Female final year foundation phase student teacher]

When opening the story the timing was too fast so I paused every slide when reading it and then pressed play. [Female final year foundation phase student teacher]

\section{The following excerpts demonstrate reflection on practice:}

I was disappointed because I hadn't achieved my outcomes. I wanted to have quite an in-depth discussion with the learners because there was so much meat to the story and it links to life skills. Time constraints and also the children said they were nervous to answer questions as you and the camera were in the classroom. Normally we have lovely discussions and everyone is so chatty. [Female final year foundation phase student teacher]

I didn't get to finish the shared reading part. I think it failed slightly as the children weren't able to read along in terms of the shared reading. The pace of the narration was too fast for them. It's tricky to slow it down too much because it's not so enjoyable to listen to a story that is a bit slow. So I should have made another version and keep the picture longer and read along with the sound off as you suggested. [Female final year foundation phase student teacher]

I should have practiced more using the technology. I knew what I wanted and needed to do with the computer but I stumbled a bit and the computer failed me so I didn't know what to do for a while there. [Female final year foundation phase student teacher]

The more children read the more fluent they become and the more they pick up so I should show it a few times and have a series of lessons. There was too much detail for one lesson. The narrations are good because they model how one is supposed to read with expression and changing of voice tone. [Female final year foundation phase student teacher]

The following excerpts illustrate reflection for practice:

My children could cope with the pace but I think what I'll do it differently next time is introduce the Life Skills lesson first, explore all the concepts and then have a story where I model the reading. I will have a version of the story with sound and without sound. [Female final year foundation phase student teacher]

If I did this again I would not change the characters but change the background and add more detail. I am a visual learner and tend to thrive on colour but I thought it might be too busy and distracting. I think a better background in the pictures would have benefitted the pictures in the story more. [Female final year foundation phase student teacher]

Now that I am back at varsity I have been thinking about lessons. In future I will let the children come up with the pictures, a series of pictures, sequence them and then we can work together and do a shared writing activity and come up with a story that goes with the pictures. Then we can all go through the process of putting the story together. The children are capable of doing this they just need a little bit of help. [Female final year foundation phase student teacher]

So I think what I should've done or what I should do when I edit it again is let the narration play and then lengthen the slide time. If the learners are following the text they can then look up and see the picture before it goes to the next one. [Female final year foundation phase student teacher]

In relation to the second study objective regarding participants' experiences and perceptions of using the DS during FP reading lessons, there were many positive experiences and challenges that were experienced. The following themes emerged.

\section{The novelty value of digital stories in promoting learner interest and engagement}

Almost all participants mentioned that DS created much excitement among FP learners during the reading lessons. They emphasised that DS generated much learner interest and engagement during the reading lessons: reflecting Bran's (2010:1791) contention that digital storytelling stimulates an increased interest in both creator and audience. DS therefore provided edutainment, a form of learning that blends entertainment with learning content with the aim of enhancing learning through increasing interest, engagement and an affective association with what is being taught (Garzotto \& Forfori 2006:114). However, a [very] few participants mentioned that DS stories did not hold much novelty value during the lessons since their learners were quite familiar with technology given their backgrounds. One student mentioned that learners:

watch C Beebies and they watch the Magic School Bus and they watch all sorts of YouTube videos, all the time that it's not really a big deal for them. [Female final year foundation phase student teacher]

Another student highlighted the importance of creating a DS that was cognitively challenging enough for learners not to become easily bored. The following excerpt illustrates this view:

My children didn't really like it, it was boring, it was too young for them but I had a whole session with them and I asked them what they like and what they don't like and one of the things that they said was, one; they could read everything. [Female final year foundation phase student teacher]

The following excerpts reflect how the use of DS captured the attention of FP learners:

After the lesson the learners could not stop talking about the D.S. and how 'cool' it was. They begged for more. [Female final year foundation phase student teacher] 
Learners paid so much attention and they were interested in all the dynamics of the whole new technological way of telling a story. They were totally swallowed up by the story, the look on their faces was heart-warming as they really paid attention to the story. [Female final year foundation phase student teacher]

The D.S. evoked interesting fantasies by the children. The discussion was more extensive, even those learners who struggle with reading were now able to be part of it without feeling exposed or afraid to share their feelings and opinions. [Female final year foundation phase student teacher]

I felt I could have done a story about anything and the learners would have liked it. It was all about experiencing a different and exciting mode of telling a story. [Female final year foundation phase student teacher]

\section{The pedagogical value of digital stories in FP reading lessons}

Despite some technical challenges experienced (discussed in the next theme) many participants were of the view that the use of DS stories enhanced the educational value of the reading lessons. They reported that FP learners seemed to experience the lessons as more meaningful, appeared to remember the content more clearly than with an ordinary reading lesson and were better able to recall the story. These observations illustrated the potential of DS as powerful teaching and learning tools (Robin 2006). These perceived pedagogical benefits may be linked to the multimodal (auditory, verbal and visual) nature of learning through the use of DS. Research has shown that multimodal learning generally seems to be more effective than traditional, unimodal learning. The addition of visuals to verbal (text and/or auditory) learning may lead to significant gains in basic and higher-order learning (Cisco 2008:14). The following excerpts reflect participants' sentiments regarding the pedagogical value of DS:

It appears that when children see/hear a story that is not static but moving they seem more able to reflect and relate it to their own lives. They seem to have their own interpretation about the same story. [Female final year foundation phase student teacher]

I seem to be using higher order questions with my D.S. and the children could answer, it could be because of the pictures and how excited the children were to watch the screen. [Female final year foundation phase student teacher]

\section{Technological challenges in using digital stories during reading lessons}

Some of the participants experienced challenges in using technology during reading lessons. These challenges were due to factors such as: inadequate infrastructure and ICT services at school such as computer and data projector availability; as well as participants' limited technological knowledge and experience in using DS. The different components (e.g. text, sounds, images, animations, verbal narrations) of a digital story should complement each other through appropriate integration so that the digital story is presented in an effective manner (Chung 2006:36). One of the technical challenges mentioned was the pace of the narration which was too fast and did not allow learners enough time to listen to the narration and at the same time read the text appearing on the screen. In some DS the background music was too loud and overshadowed the narrator's voice at times, while a few students reported that the automated turning of the DS pages did not synchronise well with the pace of narration. Such challenges are reflected in the following excerpts:

Not all classrooms are equipped with smartboards. [Female final year foundation phase student teacher]

Some of the slides were moving too fast therefore only the fastest readers were able to follow, the rest fell behind. [Female final year foundation phase student teacher]

The pages were turning too quickly and I was not sure how to slow this down. The scanner did not scan the pictures properly so I had to redo again. I would also have liked to add more sound effects to the story but I struggle to pause and do this. [Female final year foundation phase student teacher]

When playing the story on the overhead I noticed that the beautiful colours which we had drawn had not been reflected properly. The colours changed to green and black and this made the story dark. [Female final year foundation phase student teacher]

Participants reflected that in future they would conduct a 'dry run' before using a DS in a real lesson.

\section{Curriculum integration and differentiation through the use of digital stories}

Participants mentioned that DS provided opportunities for curriculum differentiation within a subject and the integration of learning across subjects. For example, the Life Skills subject's theme of space was used to create a story about space used in a reading lesson. Curriculum integration is an important consideration in the formal education of young learners. All children have distinct learning styles and by integrating curriculum a teacher is more likely to reach more learners in a way that attracts them. An integrated curriculum fuses subject areas, experiences, real- life knowledge together to make a more fulfilling learning environment for children. An integrated curriculum is all about making connections, whether to real life or across disciplines, about skills or about knowledge (Drake \& Burns 2004:7-8). Thus, the use of DS encouraged an interdisciplinary approach to learning; another characteristic of authentic learning according to Reeves et al. (2002:563). The following excerpts illustrate this point:

I was able to use the same story to consolidate different activities for the different ability groups. [Female final year foundation phase student teacher]

It seems that lots of the stories we have created can be linked to Life Skills, e.g. bullying, diversity, gender issues, friendship, morals. [Female final year foundation phase student teacher]

It seems that the reading lesson extended into the Life Skills lesson. [Female final year foundation phase student teacher]

I used the pollution theme which linked to the DS we basically did a shared writing and also an independent writing lesson that related to the crab in the story to see how they could help with pollution. The opportunities for integration are endless. [Female final year foundation phase student teacher] 


\section{Assessment and digital stories}

Some of the participants demonstrated that assessment could be integrated during lessons involving the use of DS. Classroom assessment has the potential not only to measure and report learning but also to promote it (Wren 2004). The author also maintains that assessment is an essential element to assist teachers to inform their instruction. Due to learners' different reading levels, it is necessary for teachers to design literacy instruction that meets the needs of the individuals. Burns (2005) recommends questioning as a formative assessment that involves learners: verbal questions can be used to probe learner responses. The questioning strategy can provide teachers with insight into the learners' thinking and reasoning and guide teachers and improve instruction for future lessons. Incorporating learners' reasoning into classroom discussions makes assessment an integral aspect of classroom instruction (Burns 2005:27). The following excerpts reflect how questioning and other tasks were used as a means of assessing learners' understandings during the DS lessons:

The use of prompt questions kept them interested and involved in the story. [Female final year foundation phase student teacher]

I considered Bloom's Taxonomy and it really helped me a lot to question the learners and reach them on different levels. [Female final year foundation phase student teacher]

In the introduction I mostly used higher order questions to check their understanding. [Female final year foundation phase student teacher]

I used the story for a shared reading and the writing as a platform to ask questions and teach the elements of a story. [Female final year foundation phase student teacher]

Everybody got the same input and had the same text. I was then able to do ability graded tasks but still the same context to assess their comprehension. [Female final year foundation phase student teacher]

\section{Conclusion}

This study demonstrated that the creation of DS by student teachers, was an effective way to promote collaboration, student agency, and the acquisition of pedagogical and technology skills among students within a university curriculum. Participants clearly expressed how the creation of DS had provided a challenging but authentic learning opportunity to them. This study also found that the use of DS in FP reading lessons has the potential to enhance learning and motivation among young learners. Technology is changing both in the way children read, as well as approaches to teaching reading. Reading success can be enhanced when technology is appropriately integrated with quality content to meet specific learning needs (Lamb \& Johnson 2011:56). Given the complex and dynamic world of teaching and learning, it is recommended that more research be conducted to explore the use of DS in FP classrooms with regard to student diversity in terms of: reading levels, diverse mother tongues as well as multigrade classrooms, the latter being a feature of many rural schools in South Africa.

\section{Acknowledgements Competing interests}

The authors declare that they have no financial or personal relationships which may have inappropriately influenced them in writing this article.

\section{Authors' contributions}

S.A. was responsible for preparing the participants in the design of their digital stories, the data collection, as well as the introduction and literature review of the article. T.M. was responsible for the theoretical framework, methodology as well as the discussion of findings of the study.

\section{References}

Bearne, E., 2005, 'Multimodal texts: What they are and how children use them', in J. Evans (ed.), Literacy moves on: Popular culture, new technologies, and critical literacy in the elementary classroom, pp. 16-30, Heinemann, Portsmouth, NH.

Beers, C.S., Beers, J.W. \& Smith, J.O., 2010, A principal's guide to literacy instruction. The Guilford Press, New York.

Bran, R., 2010, 'Message in a bottle telling stories in a digital world', Procedia Social and Behavioral Sciences 2, 1790-1793. http://dx.doi.org/10.1016/j.sbspro.2010. 03.986

Braun, V. \& Clarke, V., 2006, 'Using thematic analysis in psychology', Qualitative Research in Psychology 3(2), 77-101. http://dx.doi.org/10.1191/1478088706 qp063oa

Burns, M., 2005, 'Assessment to promote learning: Looking at how students reason', Educational Leadership 63(3), 26-31.

Chung, S.K., 2006, 'Digital storytelling in integrated arts education', The International Journal of Arts Education 4(1), 33-50.

Cisco Systems, 2008, 'Mulitmodal learning through the media: What the research says', viewed 01 November 2015, from http://www.cisco.com/web/strategy/ docs/education/Multimodal-Learning-Through-Media.pdf

Clarke, V. \& Braun, V., 2013, 'Teaching thematic analysis: Over-coming challenges and developing strategies for effective learning', The Psychologist 26(2), 120-123.

Damşa, C.I., 2014, 'The multi-layered nature of small-group learning: Productive interactions in object-oriented collaboration', International Journal of Computer.Supported Collaborated Learning 9, 247-281. http://dx.doi.org/10.1007/s11412014-9193-8

Drake, S.M. \& Burns, R.C., 2004, Meeting standards through integrated curriculum. Alexandria, VA, Association for Supervision and Curriculum Development.

Florez, M., 2001, 'Reflective teaching practice in adult ESL settings', ERIC Digests ED451733, 1-7.

Garzotto, F. \& Forfori, M., 2006, 'FaTe2: Storytelling edutainment experiences in 2D and 3D collaborative spaces', Proceedings of IDC 2006, ACM, New York, pp. 113-116.

Javorsky, K. \& Trainin, G., 2014, 'Teaching young readers to navigate a digital story when rules keep changing', The Reading Teacher 67(8), 606-618. http://dx.doi. org/10.1002/trtr.1259

Kikokawa, T. 2010, 'Media saturation undermines child development and parent-child relationships', JMAJ 53(1), 14-18, viewed 06 June 2016, from http://www.med. or.jp/english/journal/pdf/2010

Korthagen, F., 2001, Linking practice and theory. The pedagogy of realistic teacher education, Lawrence Erlbaum Associates, Inc, Mahwah, NJ.

Kress, G., 2003, Literacy in the new media age, Rutledge, London, UK.

Lamb, A. \& Johnson, L., 2011, 'Nurturing a new breed of reader: Five real world issues', Teacher Librarian 39(1), 56-63.

Larson, C.L., 2010, 'Digital readers: The next chapter in E-book reading and response', The Reading Teacher 64(1), 15-22. http://dx.doi.org/10.1598/RT.64.1.2

Lave, J. \& Wenger, E., 1991, Situated learning: Legitimate peripheral participation, Cambridge University Press, Cambridge, NY.

Loughran, J., 2002, 'Effective reflective practice - In search of meaning in learning about teaching', Journal of Teacher Education 53(1), 33-43. http://dx.doi. org/10.1177/0022487102053001004

Mack, N., Woodsong, C., MacQueen, K.M., Guest, G. \& Namey, E., 2005, Qualitative research methods: A data collector's field guide, Family Health International,
Durham, NC.

Matthews-DeNatale, G., 2008, Digital storytelling: Tips and resources, Boston, MA, viewed 02 February 2015, from https://net.educause.edu/ir/library/pdf/ ELI08167B.pdf

Merriam, S., 2009, Qualitative research: A guide to design and implementation, Jossey-Bass, San Francisco, CA. 
O'Hara, M., 2007, 'Strangers in a strange land: Knowing, learning and education for the global knowledge society', Futures 39, 930-941. http://dx.doi.org/10.1016/j. futures.2007.03.006

Ohler, J., 2008, Digital storytelling in the classroom, Corwin Press, Thousand Oaks, CA.

Prensky, M., 2001, 'Digital natives, digital immigrants part 1', On the Horizon 9(5), 1-6. http://dx.doi.org/10.1108/10748120110424816

Reeves, T.C., Herrington, J. \& Oliver, R., 2002, 'Authentic activities and online learning', in A. Goody, J. Herrington \& M. Northcote (eds.), Quality conversations: Research and development in higher education 25, 562-567. Jamison, ACT: HERDSA.

Robin, B.R., 2006, Educational uses of digital storytelling, viewed 05 January 2016, from https://digitalliteracyintheclassroom.pbworks.com/f/Educ-Uses-DS.pdf

Robin, B.R., 2008, 'Digital storytelling: A powerful technology tool for the 21st century classroom', Theory into Practice 47(3), 220-228.

Rule, A.C., 2006, 'Editorial: The components of authentic learning', Journal of Authentic Learning 3(1), 1-10, viewed 16 February 2015, from https://dspace. sunyconnect.suny.edu/bitstream/handle/1951/35263/editorial_rule. pdf? sequence $=1$

Ryan, M., Carrington, S., Selva, G. \& Healy, A., 2009, 'Taking a reality check: Expanding pre-service teachers' views on pedagogy and diversity', Asia-Pacific Journal of TeacherEducation37(2),155-173.http://dx.doi.org/10.1080/13598660902804303
Schön, D., 1983, The reflective practitioner - How professionals think in action, Temple Smith, London.

Schön, D., 1987, Educating the reflective practitioner, Jossey-Bass Publishers, San Francisco, CA.

Shulman, L.S. \& Shulman, J.H., 2004, 'How and what teachers learn: A shifting perspective', Curriculum Studies 36, 257-271. http://dx.doi.org/10.1080/0022 027032000148298

Terre Blanche, M. \& Durrheim, K., 1999, Research in practice, University of Cape Town Press, Cape Town.

UNESCO, 2005, 'EFA global monitoring report: Education for all: Literacy for life 2006', viewed 02 January 2016, from http://www.uis.unesco.org/Library/Documents/ gmr06-en.pdf

Wenger, E., 1998, Communities of practice: Learning, meaning, and identity, Cambridge University Press, Cambridge.

Wren, S. 2004, Descriptions of early reading assessments. Southwest Educationa Development Laboratory, viewed 14 December 2015, from http://www. balancedreading.com/assessment/assessment.pdf

Xu, Y., Park, H. \& Baek, Y., 2011, 'A new approach toward digital storytelling: An activity focused on writing self-efficacy in a virtual learning environment', Educational Technology \& Society 14(4), 181-191. 